\title{
Performance of Asphalt Mixture using Waste Materials
}

\author{
A.Ananthakumar, K.Anisha, M.Aishwarya, R.Indhumathi, S.Malathi
}

\begin{abstract}
A large number of solid wastes are being produced each day. This wastes, especially plastic and rubber effects the environment. So, nowadays these kinds of wastes are used in flexible pavements. In this project, the performance of the asphalt mixture using waste plastic and crumb rubber was determined. The aggregate were partially replaced by waste plastic $(0.5 \%, 1 \%, 1.5 \%, 2 \%, 2.5 \%)$ and crumb rubber $(0.5 \%, 1 \%, 1.5 \%, 2 \%, 2.5 \%)$. Also, $10 \%$ of fly ash is used in addition to filler material. Various tests like specific gravity, Water absorption, Impact test and Crushing strength for aggregate and softening point, Penetration test, Viscosity test, Specific gravity test and Binder content test for bitumen were conducted in obtained asphalt mixture. A Marshal stability test is also conducted to find the performance of the asphalt mixture. All the test results are compared with the results of the conventional mixture. The result obtained shows the plastic waste incorporated asphalt mixture does not affect the performance of the pavement also reduces the rutting and fatigue of the flexible pavement.
\end{abstract}

Keywords: Asphalt mixture, Binder content test, Crumb rubber, Marshall stability test, Waste plastic.

\section{INTRODUCTION}

Every country's economy mostly depends upon the industries and trades but it is all possible with transportation. The most common mode of transport in India is road transport including $90 \%$ of passengers and $70 \%$ of freight vehicles moving on roads [21]. It is very difficult to maintain roads in adverse climatic conditions. So it becomes important

Revised Manuscript Received on February 05, 2020.

* Correspondence Author

A.Ananthakumar*, Assistant Professor, Department of Civil Engineering, Vivekanandha College of Technology for Women, Tiruchengode, India. Email:ananthaakumar7410@gmail.com

K.Anisha, UG Student, Department of Civil Engineering, Vivekanandha

College of Technology for Women, Tiruchengode, India.

Email:anishacivil10@gmail.com

M.Aishwaya, UG Student, Department of Civil Engineering

Vivekanandha College of Technology for Women, Tiruchengode, India.

Email:aishwayramahendran1001@gmail.com

R.Indhumathi, UG Student, Department of Civil Engineering, Vivekanandha College of Technology for Women, Tiruchengode, India.

S.Malathi, UG Student, Department of Civil Engineering, Vivekanandha College of Technology for Women, Tiruchengode, India.

(C) The Authors. Published by Blue Eyes Intelligence Engineering and Sciences Publication (BEIESP). This is an open access article under the CC BY-NC-ND license (http://creativecommons.org/licenses/by-nc-nd/4.0/) to modify the properties of roads surface in order to reduce the increasing maintenance problems [1]. Materials like rubber and plastic can help in modifying the properties of roads as it is flexible in nature and can be mixed easily with bitumen for flexible pavements. Rubber and plastic is a non biodegradable material [3].

Aggregates which are totally nature dependent obtained from natural quarries that are depleting due to excessive usage. Continuous explosives are used on these quarries and have disturbed the natural structure of these rocks, as a result, they have loosened and during rainy seasons they collapse and the debris cause notable damage to life and property. Replacement to aggregates is necessary by considering future problems [19]. Efficient amounts of wastes, like rubber and plastic, can be replaced as aggregates up to some amount in the road construction without hampering the strength of the road. The principle element of tire is rubber and plastic, about $85 \%$ of the tire were both synthetic and natural rubber may used. Natural rubber is an elastic hydrocarbon polymer while synthetic rubber is a thermoset polymeric material. Rubber is a polymeric material that may be obtained from natural or synthetic rubber by polymerization. The rubber is melting at $180^{\circ} \mathrm{C}$ and has no effect of temperature stresses up to certain limits.

The disposal of rubber and plastic leads to environmental pollution. Therefore, utilizing waste rubber and plastic in road pavements imparts the properties of roads and to the environment as well [16]. The cost of natural construction materials are increasing day by day, so it becomes necessary to find alternatives to replace the natural resources which may lead to improved quality of roads and reduced construction costs. Rubber tyres and plastic PET bottles have been proved user-friendly to the people in many ways but those are not eco-friendly. So it becomes a matter of at most importance to reuse waste rubber and plastic in any means possible. Reusing is a partial replacement of road materials like aggregate, which can be an environmentally friendly approach [22]. Therefore, the use of waste tire rubber and plastic PET bottles has been thought to utilize as an aggregate in partial replacement in the coarse aggregate to save nature. 


\section{ORGANIZATION OF THE PROJECT}

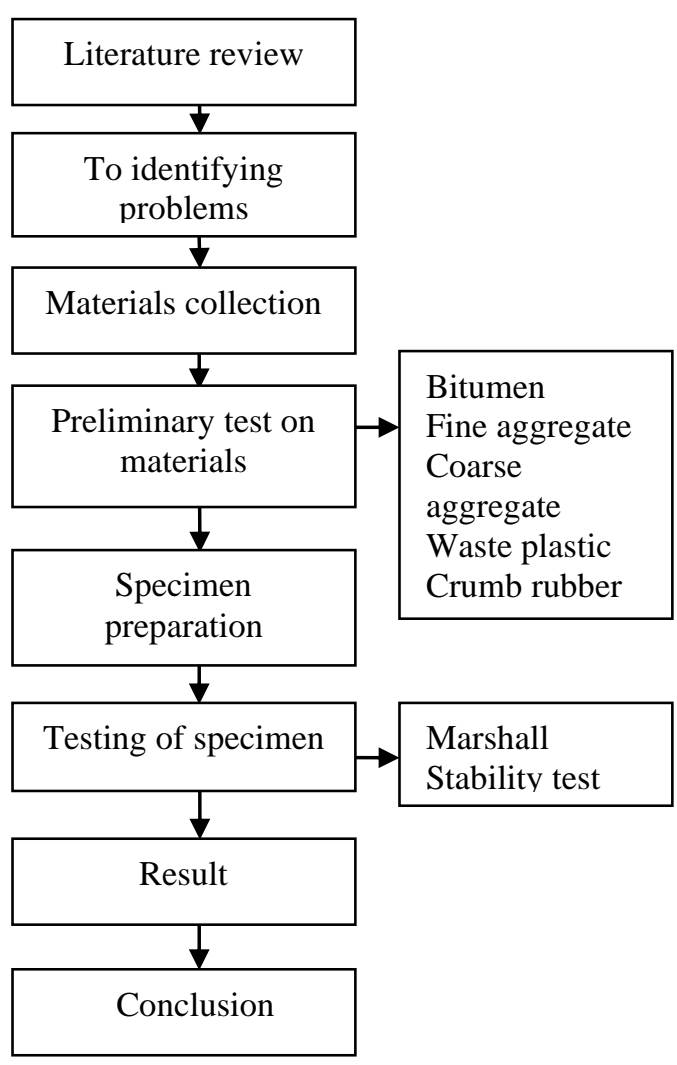

\section{PROJECT SIGNIFICANCE}

The use of waste plastic and crumb rubber in road construction is not new. The replacement of aggregate technology is not only strengthened the road construction but also increase road life. The effect of replacement of waste plastic and crumb rubber is reducing the rupture and fatigue of the flexible pavement [7]. By using plastic and crumb rubber in flexible pavement design, the problem of waste plastic and crumb rubber disposal gets solved as well as the performance of roads gets improved.

\section{MATERIALS REQUIRED}

\section{A. Aggregate}

The aggregates are bound together either by bituminous materials or by cement. In a few cases, when fly ash is mixed with waste it forms slurry which acts as a binding medium. Stone aggregate used for road work should be hard, tough, durable and hydrophobic for the bituminous surface. Gravel should be well-graded $(12 \mathrm{~mm})$ and should have a fitness modulus not less than $10 \mathrm{~mm}$.

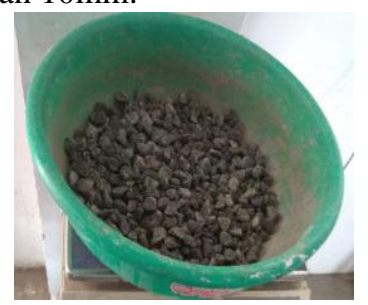

\section{B. Bitumen}

Figure 1.Coarse aggregate

Bituminous materials or asphalts are lengthily used for roadway construction, primarily, because of their excellent binding characteristics and waterproofing properties and relatively low cost. Bituminous materials consist of bitumen which is a black or dark-colored solid or viscous cementations substances consists chiefly high molecular weight hydrocarbons derived from the distillation of petroleum or natural asphalt, has adhesive properties, and it is soluble in carbon disulphide.

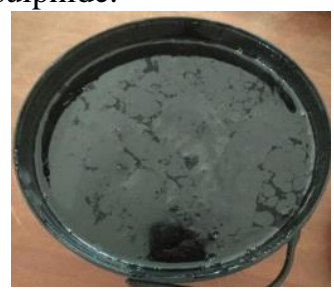

Figure 2. Bitumen

\section{Waste plastic}

In this project, a waste plastic bottle (PET) was used as a modifier additive in hot mix asphalt. To this end, PET bottles were cut into small pieces and crushed by a special crusher. Finally, crushed particles were sieved to obtain the needed gradation. The related components of studied PET were terephthalic and ethylene glycol monomers.

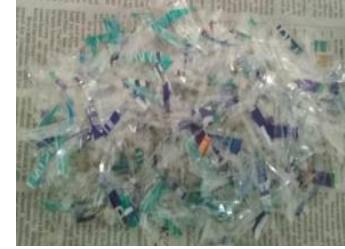

Figure 3, Plastic scrap

\section{Crumb rubber}

Used waste tubes are collected on a large scale and subjected to shredding and chipping process. These are applied using an automatic machine that can cut up the tube into tiny particles of various sizes.

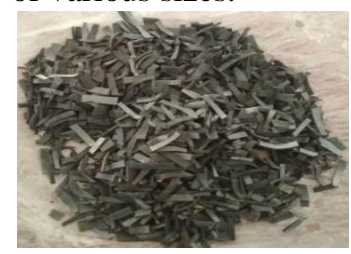

Figure 4, Crumb rubber

\section{E. Filler material}

Fly ash was produced from cement industries in all states of India. Fly ash used in this study can be classified as class F. The particle size ranging between $0.075 \mathrm{~mm}$ and $30 \mathrm{~mm}$ whereas fly ash consisted mainly of fine particles less than $300 \mu \mathrm{m}$. Fly ash content $10 \%$ are added by the weight of aggregate. The specific gravity of fly ash is 2.225 .

\section{TESTING OF MATERIALS}

\section{A. Specific gravity test on aggregate}

Specific Gravity is the ratio of the weight of a given volume of aggregate to the weight of an equal volume of water. Water, at a temperature of $73.4^{\circ} \mathrm{F}\left(23^{\circ} \mathrm{C}\right)$, has a specific gravity of 1 Specific Gravity is important for several reasons. Some deleterious particles are lighter than the good aggregates. 


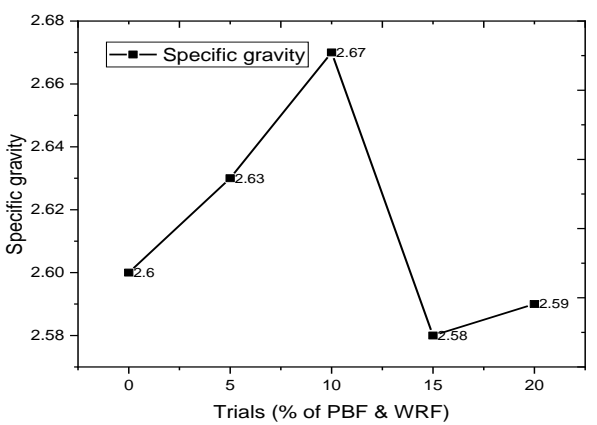

Graph 1, Specific Gravity test on aggregate

\section{B. Water absorption test on aggregate}

A specific gravity test of aggregate is done to measure the strength or quality of the material while the water absorption test determines the water holding capacity of the coarse aggregate. The main objective of this test is to measure the strength or quality of the material.

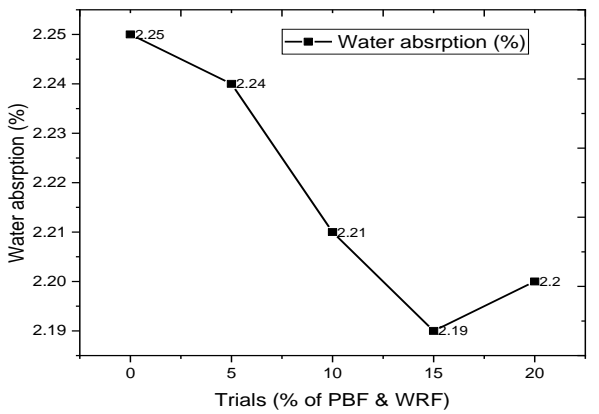

Graph 2, water absorption test on aggregate

\section{Impact test on aggregate}

The property of a material to resist the impact is known as the toughness of coarse aggregate. This characteristic is measured by the impact value test. The aggregate impact value measures the resistance of sudden impact or shock, which may differ from its resistance to gradually applied compressive load.

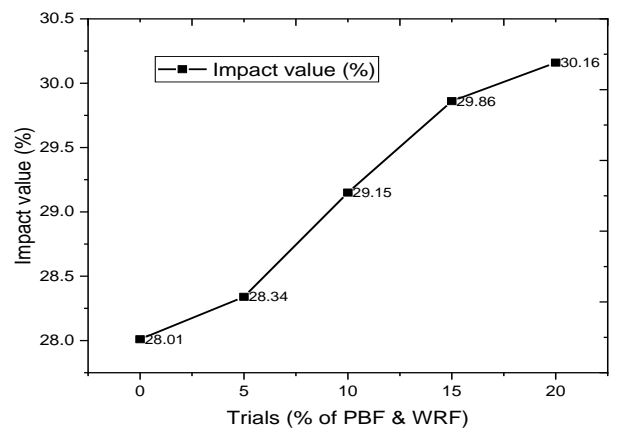

Graph 3, Impact test on aggregate

\section{Crushing strength test on aggregate}

The strength of coarse aggregate is assessed by aggregate crushing test. The aggregate crushing value provides a relative measure of resistance to crushing under a gradually applied compressive load. To achieve a high quality of pavement, aggregate possessing low aggregate crushing value should be preferred.

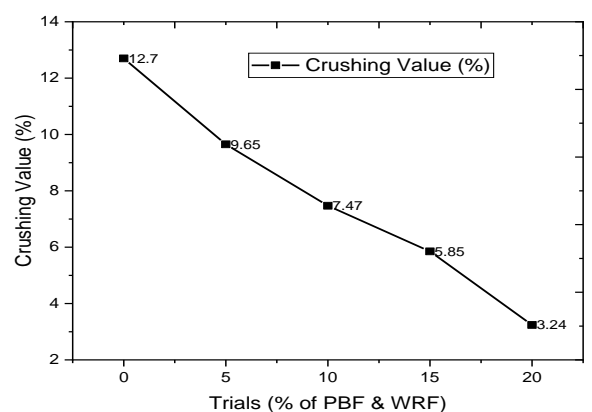

\section{Graph 4, Crushing strength test on aggregate}

\section{E. Specific gravity test on bitumen}

This test is done to determine the specific gravity of semi-solid bitumen road tar. The principles are that it is the ratio of the mass of a given volume of bitumen to the mass of an equal volume of water, both are at a recorded at a specified temperature.

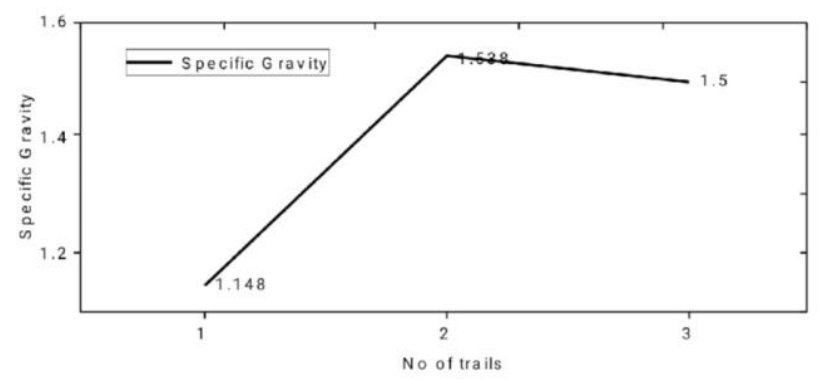

Graph 5, Specific gravity test on Bitumen

\section{F. Softening point test on bitumen}

Temperature is noted when the softened bitumen touches the metal plate which is at a specific distance below. Generally, a higher softening point indicates lower temperature susceptibility and it is preferred in hot climates.

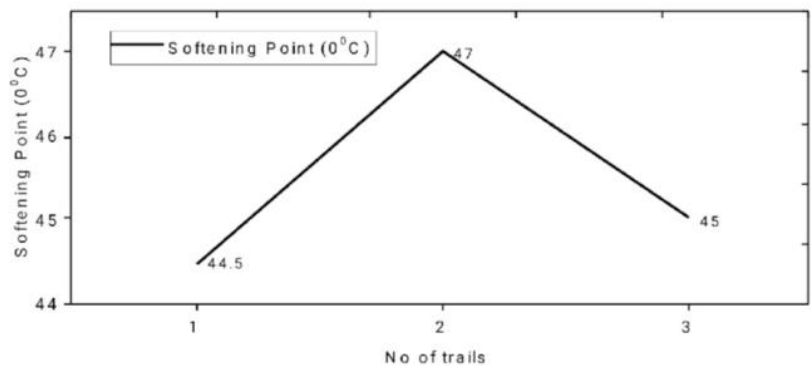

Graph 6, Softening point test on bitumen

\section{G. Ductility test on bitumen}

Ductility of a bitumen material is measured by the distance in millimeters to which it will elongate before breaking when two ends of standard briquette specimen of material are pulled apart at a specified speed and specified temperature. 


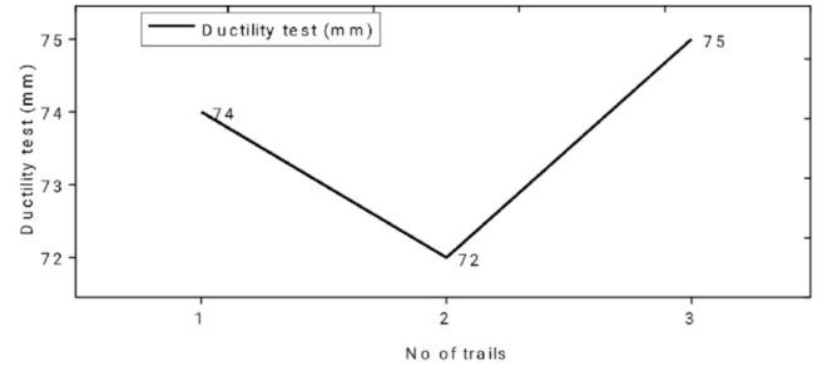

Graph 7, Ductility test on bitumen

\section{H. Viscosity test on bitumen}

Saybolt Furol viscosity test is used to determine the viscosity of liquid bitumen. In this test, time in seconds is noted for $60 \mathrm{ml}$ of the liquid bitumen at a specified temperature to flow through an office of a specific size. The higher viscosity of the bitumen requires more time for quality to flow out.

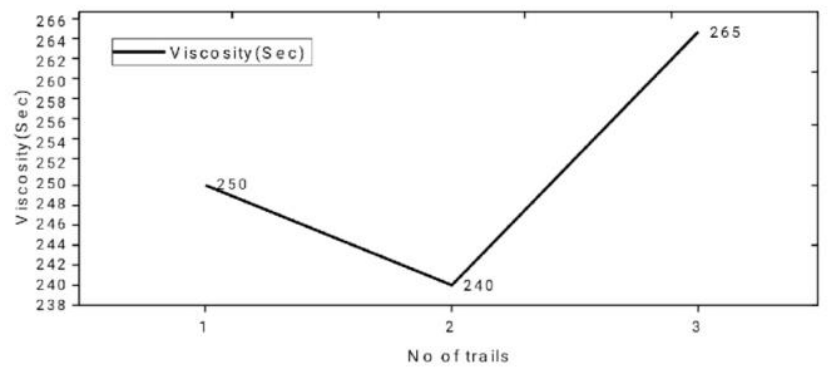

Graph 8 , Viscosity test on bitumen

\section{Penetration test on bitumen}

The penetration test of bitumen is a test where a standard penetration needle [Carrying 100 gm superimposed load] is allowed to penetrate a standard bitumen sample for standard time period [ 5 seconds], at standard test temperature $\left[25^{\circ} \mathrm{C}\right]$ and the value of penetration is expressed as $1 / 10^{\text {th }}$ of $\mathrm{mm}$.

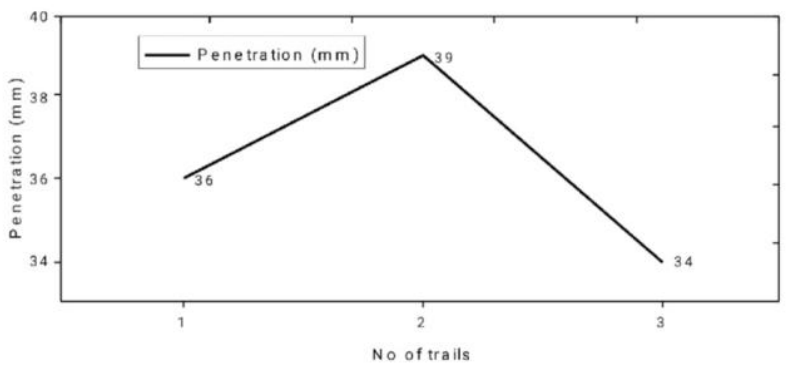

Graph 9, Penetration test on bitumen

\section{J. Binder content test on bitumen}

The determination of the binder content of the bituminous mixture is one of the major properties that affect pavement performance. The binder content affects the pavement's tendency to permanent deformation, fatigue cracking, and moisture damage. The binder content can be determined by the ignition method and hot/cold extraction.

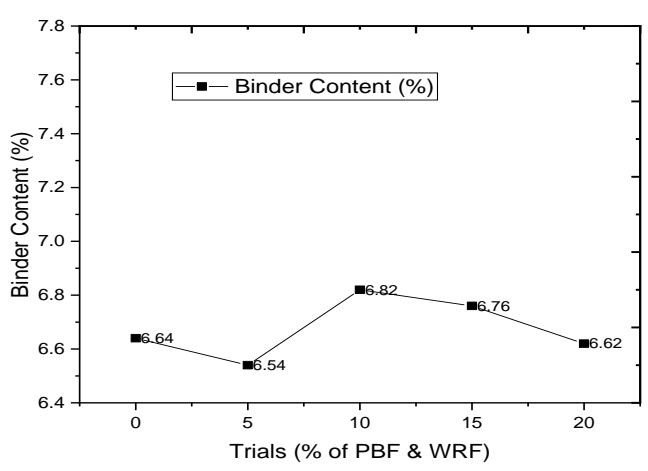

Graph 10, Binder content test on bitumen

K. Material test results and analysis
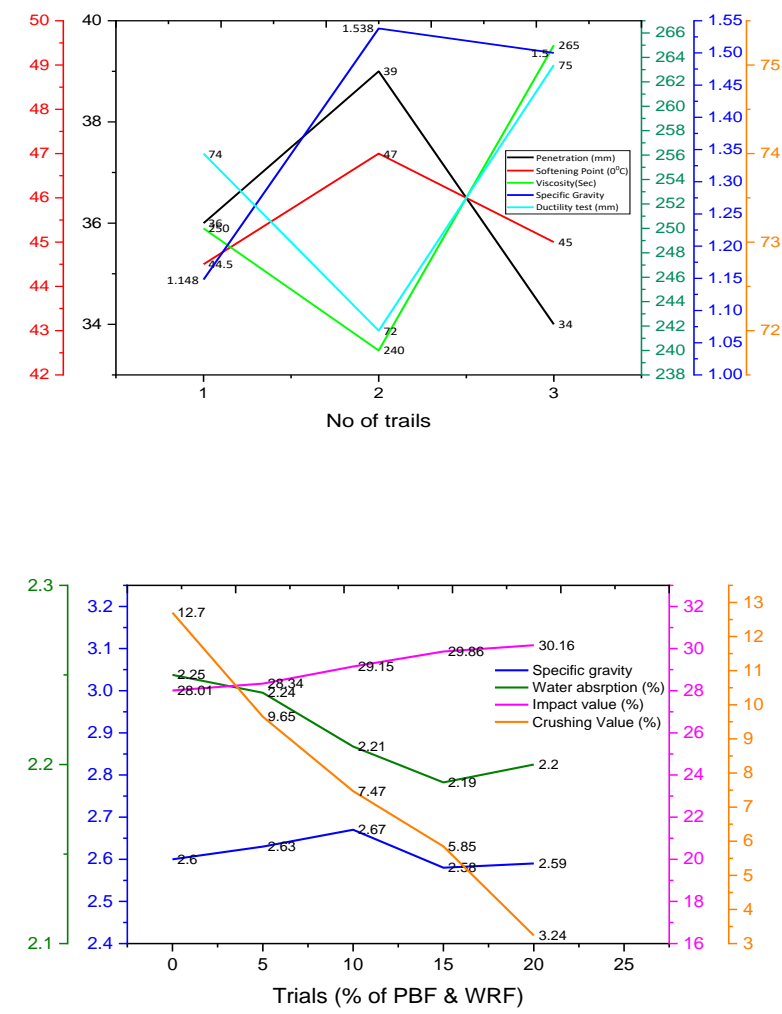

Graph 11,12, Result Analysis of Aggregate and Bitumen.

\section{MARSHALL STABILITY TEST ON SAMPLES}

The bituminous concrete mix is commonly designed by the Marshall Stability method. This test is extensively used in routine test programmers for paving jobs. The stability of the mix is defined as the maximum load carried by a compacted specimen at a standard test temperature of $60^{\circ} \mathrm{C}$. The flow is measured as the deformation in units of $0.25 \mathrm{~mm}$ between no-load and maximum load carried by the specimen during the stability test (flow value of $0.1 \mathrm{~mm}$ ). This test attempts to get the optimum binder content for the aggregate mix type and traffic intensity. This is the test that helps us to draw Marshall Stability vs. bitumen content and Marshall Stability vs. bitumen content. 


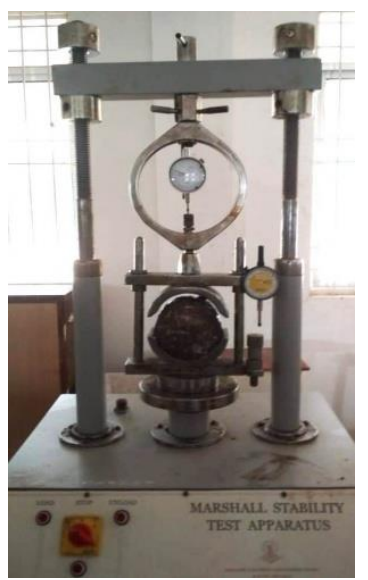

Figure 5, Marshall Stability test on samples

Table I. Marshall Stability test Values

\begin{tabular}{|c|c|c|c|c|c|c|}
\hline $\begin{array}{c}\text { Particu } \\
\text { lars }\end{array}$ & $\begin{array}{l}\text { Sa } \\
\text { mp } \\
\text { le-1 }\end{array}$ & $\begin{array}{c}\begin{array}{c}\text { Sam } \\
\text { ple- } \\
2\end{array} \\
\end{array}$ & $\begin{array}{c}\text { Samp } \\
\text { le-3 }\end{array}$ & $\begin{array}{c}\text { Sample- } \\
4\end{array}$ & $\begin{array}{c}\text { Sample } \\
-5\end{array}$ & $\begin{array}{c}\text { Samp } \\
\text { le-6 }\end{array}$ \\
\hline $\begin{array}{c}\text { Percent } \\
\text { age of } \\
\text { waste } \\
\text { materia } \\
\text { ls }(\%)\end{array}$ & 0 & 0.5 & 1 & 1.5 & 2 & 2.5 \\
\hline $\begin{array}{l}\text { Weight } \\
\text { of } \\
\text { specim } \\
\text { en in } \\
\text { air (g) }\end{array}$ & $\begin{array}{c}130 \\
9\end{array}$ & 1243 & 1228 & 1189 & 1145 & 1180 \\
\hline $\begin{array}{c}\text { Weight } \\
\text { of } \\
\text { specim } \\
\text { en in } \\
\text { water } \\
\text { (g) }\end{array}$ & $\begin{array}{c}105 \\
5\end{array}$ & 995 & 978 & 954 & 897 & 871 \\
\hline $\begin{array}{l}\text { Weight } \\
\text { of } \\
\text { saturat } \\
\text { ed } \\
\text { surface } \\
\text { dry } \\
\text { core (g) } \\
\end{array}$ & $\begin{array}{c}133 \\
4\end{array}$ & 1278 & 1257 & 1215 & 1196 & 1153 \\
\hline $\begin{array}{l}\text { Volume } \\
\text { of core } \\
\text { (cc) }\end{array}$ & 279 & 283 & 279 & 261 & 299 & 282 \\
\hline $\begin{array}{l}\text { Density } \\
\text { of core } \\
\text { (g/cc) }\end{array}$ & $\begin{array}{c}4.6 \\
9\end{array}$ & 4.39 & 4.4 & 4.56 & 3.83 & 3.93 \\
\hline $\begin{array}{l}\text { Marsha } \\
\text { Il } \\
\text { Stabilit } \\
\text { y (kN) } \\
\end{array}$ & 24 & 26 & 29 & 19 & 10 & 9 \\
\hline $\begin{array}{l}\text { Flow } \\
\text { value } \\
(\mathrm{mm})\end{array}$ & $\begin{array}{l}2.0 \\
48\end{array}$ & $\begin{array}{c}2.01 \\
5\end{array}$ & 1.995 & 2.08 & 1.79 & 1.705 \\
\hline $\begin{array}{c}\text { Marsha } \\
\text { Il } \\
\text { Quotie } \\
\text { nt } \\
\end{array}$ & $\begin{array}{l}11 . \\
72\end{array}$ & $\begin{array}{c}12.9 \\
1\end{array}$ & 14.54 & 9.13 & 5.58 & 5.27 \\
\hline $\begin{array}{c}\text { Bitume } \\
\text { n } \\
\text { content } \\
(\%) \\
\end{array}$ & 5 & 5.23 & 5.5 & 4.83 & 4.18 & 4.03 \\
\hline
\end{tabular}

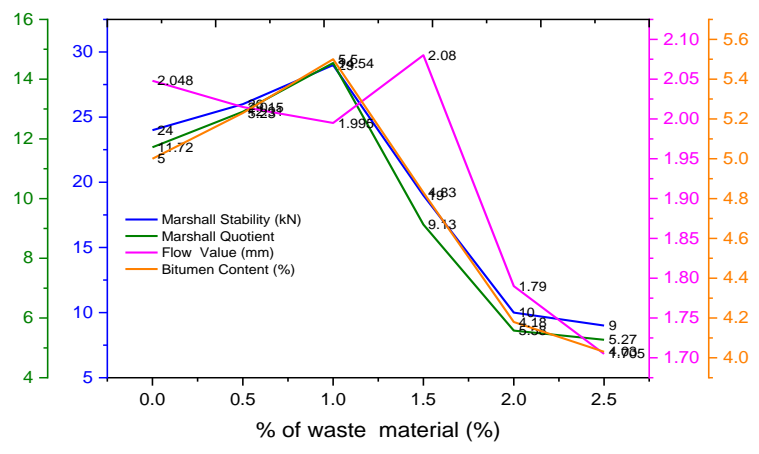

Graph 13, Marshall Stability test value of Specimens

From this project, It states that with the use of waste plastic, crumb rubber and filler materials becomes better than the ordinary bitumen mixture. Moreover, the plastic and rubber bitumen is more resistant to the rupture and fatigue of the flexible pavement.

\section{CONCLUSION}

Based on the above project result, the following conclusions are drawn:

1. $1 \%$ of plastic and crumb rubber replacement in aggregate gives a better result for flexible pavement construction.

2. Plastic and crumb rubber as a $1 \%$ replacement in aggregate can be used as an optimum percentage value for the bituminous mixture.

3. Plastic and crumb rubber can be utilized as a fractional blending material in the design of flexible pavement.

4. $1 \%$ replacement of aggregate sample specimen gives a high stability value than the conventional specimen.

5. $1.5 \%$ replacement of aggregate sample specimen gives a high flow value than the specimen.

This project gives a satisfactory conclusion by replacing aggregate. Waste plastic and crumb rubber give the more Marshall Stability value and flow value than the conventional. This project also reduces the bitumen content for asphalt mixture. This project is reducing the aggregate content for the flexible pavement construction and in reducing the environmental impacts of waste disposal.

\section{REFERENCES}

1. Sowmya N J, Athira R Prasad (2015),'Bitumen Modification with Waste Plastic and Crumb Rubber", International Journal of Engineering Research and Technology, ISSN:2278-0181, Vol.4, Issue 05.

2. Abdul Manan, Sandeep Singal, Manish Kaushal(2018),"A Study on Comparison of Plastic Bitumen and Crumb Rubber Bitumen", International Journal for Research in Applied Science and Engineering Technology ,Vol.6, Issue 10.

3. Bhadane Rupesh Umrao (2019),'Use of waste plastic and 


\section{Performance of Asphalt Mixture using Waste Materials}

crumb rubber in construction of flexible pavement", International Journal of Advance Research, Ideas and Innovation in Technology , Vol.5, Issue 2.

4. Nimisha P R, Muhammed shahid P T, Krishna Priya K U, Muhnis Mohammed, Raveena Jobbi (2018) ,'Experimental Studies on The Properties of Modified Bituminous Mixes Using Crumb Rubber", Vol.05, Issue 08.

5. Anusha G Krishna(2018),"Waste Plastic and Crumb Rubber in Flexible Pavement",International Journal of Applied Engineering Research, Vol.13,Number 7 pp.135-138.

6. Ahmad M. Abu Abdo(2017)," Investigation The Effects of The Adding Waste Plastic on Asphalt Mixes Performance",ARPN Journal of Engineering and Applied Science, Vol.12,Number 15.

7. GH.Shafabakhsh, M.Sadeghnejad, Y.Sajed(2014),"Case Study of Rutting Performance of HMA Modified with Waste Rubber Powder",Case Studies in Construction Materials.

8. Bin Yu, Liya Jino, Fujian Ni, Jun Yang(2014),"Evaluation of plastic-rubber asphalt:Engineering property and environmental concern", Construction and Building Materials 71, pp 416-424.

9. Amir Modarres, Hamidreza Hamedi (2014)," Effect of waste plastic bottles on the stiffness and fatigue properties of modified asphalt mixes" Materials and Design 61, pp 8-15.

10. Imran M. Khan, Shahid Kabir, Majed A. Alhussain, Feras F Almansoor(2016),"Asphalt Design using Recycled Plastic and Crumb-rubber Waste for Sustainable Pavement Construction",International Conference on Sustainable Design, Engineering and Construction 145, pp 1557-1564.

11. Sunil Khuntia, Aditya Kumar Das, Monika Mohanty, Mahabir Panda(2014),"Prediction of Marshall Parameters of Modified Bituminous Mixtures Using Artificial Intelligence Techniques,'International Journal of Transportation Science and Technology Vol 3,No 3,pp 211-228.

12. Yanping Sheng, Haibin Li, Jiuguang Geng, Yu Tain, Zuzhong Li, Rui Xiong(2017)," Production and Performance of Desulfurized Rubber Asphalt Binder,'International Journal of Pavement Research and Technology.

13. Dharamveer Singh, Dheeraj Sawant, Feipeng Xiao(2017),'High and intermediate temperature performance evaluation of crumb rubber modified binders with RAP," Transportation Geotechnics ,10(2017)13-21.

14. Shubham Bansal, Anil Kumar Misra, Purnima Bajpai(2017),' Evaluation of modified bituminous mix developed using rubber and plastic waste materials," International Journal of Sustainable Built Environment.

15. Mohammad Fallah Tafti, Mohammad Mehdi Khabiri, Hamed Khain Sanji(2016)," Experimental Investigation of the Effect of Using Different Aggregate types on WMA Mixtures",International Journal of Pavement Research and Technology.

16. R.Manju, S.Sathya, K.Sheema(2017),'Use of Plastic Waste in Bituminous Pavement", International Journal of ChemTech Research, ISSN :0974-4290, Vol.10 no.08, pp 804-811.

17. Liliana M.B.Costa, Hugo M.r.D.Silva, Joel R.M. Oliveira, Sara R.M Fernandes(2013),'Incorporation of Waste Plastic in Asphalt Binders to Improve Their Performance in the Pavement", International Journal of Pavement Research and Technology,ISSN :1996-6814,pp 457-464.

18. Piyush G. Chandak, Anand B.Tapase, Ravindra P.Patil, Sabir S.Sayyed, Abdulrashid C.Attar(2019),'Utilizing different wastes in rural roads of India", International Journal of Innovative Technology and Exploring Engineering, ISSN :2278-3075, Vol-8, Issue 11.

19. Bhavesh Bafna, Poonam Bhandare, N.M.Patil , Sanchit Jadhave, Santosh Koravi, Hanmant Pujari(2019),"Use of Plastic Aggregate and Crumb Rubber in Flexible Pavement", International Research Journa of Engineering and Technology, Vol-06, Issue 03

20. Minati Mohanty, Sagarika Panda(2019),'Crumb Rubber: A Sustainable Road Paving Material", International Journal of Innovative Technology and Exploring Engineering, ISSSN : 2278-3075, Vol-8, Issue- 10 .

21. Harpalsinh raol, Abhijitsinh Parmar, Dhaval Patel , Jitendra Jayswal(2014),"Effect of the use of Crumb Rubber in Conventional Bitumen on the Marshall Stability Value", International Journal of Research in Engineering and Technology,eISSN : 2319-1163, pISSN : 2321-7308, Vol-03, Issue :01.

22.Rokade S(2012),"Use of Waste Plastic and Waste Rubber Tyres in Flexible Highway Pavements", International Conference on Future Environment and Energy, IPCBEE Vol-28.

\section{AUTHORS PROFILE}

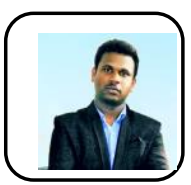

A.Ananthakumar M.E.,(Ph.D.)., I am working as an Assistant Professor at Vivekanandha College of Technology for Women, Tiruchengode. I am pursuing a Ph.D. at Anna University, Chennai. I am one of the Associate Member of the Institution of Engineers in India. I received one award for "YOUNG SCIENTIST - 2019" from AIRF, Tiruvannamalai. I published 16 international journals. I submitted one research paper for Annexure 1 journal. I present the paper for three international conferences and two national conferences in various colleges. I had delivered one guest lecture on "Experimental Study on External Reinforced Glass Beams" at IE(I) Training Centre in BHEL Campus. I attended six workshops and five Faculty Development programs in various colleges. I participated in 2 national seminars in various colleges. I successfully completed two NPTEL courses conducted by IITM and also completed GIS course.

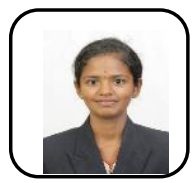

K.Anisha, I am studying undergraduate in the department of civil Engineering, Vivekanandha College of Engineering for Women, Tiruchengode. I did Higher Secondary in School at St.Ann's Girls Higher Secondary School, Krishnagiri. I have successfully completed the program requirements of AUTOCAD at Vivekanadha Educational Institutions, Namakkal. I have more interest in research work. I am one of the Member of the Indian Concrete Institute. I attended four seminars and three workshops in various colleges. And I participated in one national level symposium in our college. I participated in TNSCST sponsored National Level Seminar on "Waste Water Management". I had to give a presentation about my mine project at the National level conference.

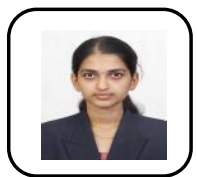

M.Aishwarya, I am studying undergraduate in the department of civil Engineering, Vivekanandha College of Engineering for Women, Tiruchengode. I did Higher Secondary in SchoolSri Avinashilingam Girls Higher Secondary School, Coimbatore. I have successfully completed the program requirements of AUTOCAD at Vivekanadha Educational Institutions, Namakkal. I have more interest in research work. I am one of the Member of the Indian Concrete Institute. I attended two seminars and one workshop in various colleges. And I participated in one national level symposium in our college. I participated in TNSCST sponsored National Level Seminar on "Waste Water Management". I did three mini projects in my previous years.

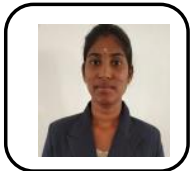

R.Indhumathi, I am studying undergraduate in the department of civil Engineering, Vivekanandha College of Engineering for Women, Tiruchengode. I did Higher Secondary in School at Fathima Girls Higher Secondary School, Salem. I have successfully completed the program requirements of AUTOCAD at Vivekanadha Educational Institutions, Namakkal. I have more interest in research work. am one of the Member of the Indian Concrete Institute. I attended two seminars and one workshop in various colleges. And I participated in one national level symposium in our college. I participated in TNSCST sponsored National Level Seminar on "Waste Water Management". I did one internship at Salem.

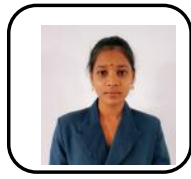

S.Malathi, I am studying undergraduate in the department of civil Engineering, Vivekanandha College of Engineering for Women, Tiruchengode. I did Higher Secondary in School at Government Higher Secondary School, Salem.I have successfully completed the program requirements of AUTOCAD at Vivekanadha Educational Institutions, Namakkal. I have more interest in research work. I am one of the Member of the Indian Concrete Institute. I attended two seminars and one workshop in various colleges. And I participated one national level symposium in our college. I participated in TNSCST sponsored National Level seminar on "Waste Water Management". I did one mine project in my previous years. 